\title{
Molecular identification and genetic diversity of open reading frame 7 field isolated porcine reproductive and respiratory syndrome in North Sumatera, Indonesia, in the period of 2008-2014
}

\author{
Faisal Faisal ${ }^{1,2}$, Rini Widayanti ${ }^{3}$, Aris Haryanto ${ }^{3}$ and Charles Rangga Tabu ${ }^{4}$
}

1. Department of Veterinary Science, Faculty of Veterinary Medicine, Gadjah Mada University, Yogyakarta, Indonesia; 2. Department of Molecular Biology, Animal Disease Investigation Centre of Medan, North Sumatera, Indonesia;

3. Department of Biochemistry, Faculty of Veterinary Medicine, Gadjah Mada University, Yogyakarta, Indonesia;

4. Department of Pathology, Faculty of Veterinary Medicine, Gadjah Mada University, Yogyakarta, Indonesia.

Corresponding author: Faisal Faisal, e-mail: faisal.dvm@gmail.com, RW: riniwida@yahoo.co.uk, AH: arisharyanto@yahoo.com, CRT: charles@ugm.ac.id

Received: 11-03-2015, Revised: 13-06-2015, Accepted: 22-06-2015, Published online: 16-07-2015

doi: 10.14202/vetworld.2015.875-880 How to cite this article: Faisal F, Widayanti R, Haryanto A, Tabu CR (2015) Molecular identification and genetic diversity of open reading frame 7 field isolated porcine reproductive and respiratory syndrome in North Sumatera, Indonesia, in the period of 2008-2014, Veterinary World 8(7): 875-880.

\begin{abstract}
Aim: Molecular identification and genetic diversity of open reading frame 7 (ORF7) of field isolated porcine reproductive and respiratory syndrome virus (PRRSV) in North Sumatera, Indonesia, in the period of 2008-2014.

Materials and Methods: A total of 47 PRRSV samples were collected from the death case of pigs. The samples were collected from different districts in the period of 2008-2014 from North Sumatera province. Two pairs of primer were designed to amplify ORF7 of Type 1 and 2 PRRSV based on the sequence of reference viruses VR2332 and Lelystad. Viral RNAs were extracted from samples using PureLink ${ }^{\mathrm{TM}}$ micro-to-Midi total RNA purification system (Invitrogen). To amplify the ORF7 of PRRSV, the synthesis cDNA and DNA amplification were performed by reverse transcription polymerase chain reaction (RT-PCR) and nested PCR method. Then the DNA sequencing of PCR products and phylogenetic analysis were accomplished by molecular evolutionary genetics analysis version 6.0 software program.
\end{abstract}

Results: RT-PCR and nested PCR used in this study had successfully detected of 18 samples positive PRRS virus with the amplification products at $703 \mathrm{bp}$ and 508bp, respectively. Sequencing of the ORF7 shows that 18 PRRS viruses isolated from North Sumatera belonged to North American (NA). JXA1 Like and classic NA type viruses. Several mutations were detected, particularly in the area of nuclear localization signal (NLS1) and in NLS2. In the local viruses, which were related closed to JXA1 virus; there are two differences in amino acids in position 12 and 43 of ORF7. Our tested viruses showed that the amino acid positions 12 and 43 are Asparagine and Arginine, while the reference virus (VR2332, Lelystad, and JXA1) occupied both by Lysine. Based on differences in two amino acids at position 12 and 43 showed that viruses from North Sumatera has its own uniqueness and related closed to highly pathogenic PRRS (HP-PRRS) virus (JXA1).

Conclusion: The results demonstrated that North Sumatera type PRRS virus has caused PRRS outbreaks in pig in North Sumatera between 2008 and 2014. The JAX1 like viruses had unique amino acid residue in position 12 and 43 of asparagine and lysine, and these were genetic determinants of North Sumatera viruses compared to other PRRS viruses.

Keywords: Indonesia, North Sumatera, open reading frame 7, porcine reproductive and respiratory syndrome virus.

\section{Introduction}

Porcine reproductive and respiratory syndrome virus (PRRSV) is an infectious disease in pigs which is caused by a virus and brings about an economic loss in pig breeding industry [1]. The first isolation of Type 1 PRRS virus (European) is called Lelystad virus, which was found in the Netherlands, and Type 2 PRRS virus (North American [NA]), called VR-2323 virus, was isolated in the United States in 1992 [2,3]. The two types of virus belong to RNA virus, enveloped, belong to Arteriviridae family, short chain, and no segment [2].

In 2006, PRRS virus became the important disease in China because of its high morbidity and mortality, which caused the death of millions of pigs.

Copyright: The authors. This article is an open access article licensed under the terms of the Creative Commons Attributin License (http:// creative commons.org/licenses/by/2.0) which permits unrestricted use, distribution and reproduction in any medium, provided the work is properly cited.
The result of the analysis on clinical symptoms, pathogenicity, and molecular virus showed that this virus was very different from classic PRRS virus so that this virus was then known as highly pathogenic PRRS (HP-PRRS) [4,5]. HP-PRRS has recently been reported in Thailand, Vietnam, Laos, Cambodia, Myanmar, Philippines, and Russia [6-8].

Open reading frame 7 (ORF7) had 123-128 amino acid which consists of N-terminal RNA binding domain and $\mathrm{C}$-terminal dimerization domain [9]. The ORF7 encodes nucleocapsid $(\mathrm{N})$ protein, is frequently performed because it is highly immunogenic in pigs and has an important role in virus virulence and diagnosis [10]. N protein is expressed abundantly and has high immunogenicity so that this protein is generally used as material in diagnostic test [11]. Glycoprotein is a conserved area so that it is frequently used for diagnostic application such as reverse transcription polymerase chain reaction (RT-PCR) and 
RT-qPCR $[5,12,13]$. The N protein has also been used for investigating genetic variation and phylogenetic relationships among PRRSV isolates [14,15].

In Indonesia, PRRS disease has not been known by many people. PRRS virus infection occurred in North Sumatera in 2008, but official information about this disease was difficult to obtain. The limitation of the data of the dynamic of PRRS disease in Indonesia had encouraged the researcher to conduct a study on it. In the present study, we determined the complete ORF7 sequences of 18 PRRS viruses from North Sumatera Province. The aims of this study were (1) To find out the genetic database for the ORF7 gene in North Sumatera PRRSV viruses; (2) to compare North Sumatera PRRSV ORF7 sequences with the ORF7 sequences of the reference viruses, (3) to determine the phylogenetic relationships between North Sumatera PRRSVs and reference viruses.

\section{Materials and Methods}

Ethical approval

This research was conducted after approval by institutional research committe of Gadjah Mada University.

\section{Sample collection}

A total of 47 samples were collected from the death case of pigs. The samples were collected from different districts in the period of 2008-2014 in North Sumatera.

\section{Primers}

In this study, two pairs of primer which was able to amplify ORF7 in Type 1 and 2 PRRS viruses. The two pairs were designed by using isolate reference VR2332, Lelystad, and also used multi alignment from the sequences of the two virus types, which were available in GenBank data. Primer3 software (http:// primer3.ut.ee/) was used to help in designing the primers for this study. The specific primers ORFF-5'GCCCTAATTGACTAGGTGACT-'3 and ORFR-5'GCCCTAATGACTAGGTGACT-'3, were designed on the ORF6 and 3'UTR sequences to generate a $703 \mathrm{bp}$ fragment including the whole ORF7 sequence. The second PCR was performed using the primers described by Guarino [16].

\section{Synthesis of cDNA and external PCR}

Total RNA was isolated from samples by PureLink ${ }^{\mathrm{TM}}$ micro-to-Midi total RNA purification system (Invitrogen) according to the instructions of the manufacturer. In RT, we used of SuperScript III FirstStrand Synthesis (Invitrogen). RT contained the following ingredients: $5 \mu 1$ of RNA, $1-\mu 1(50 \mu \mathrm{M})$ primer oligo (dT) $20,1-\mu 1(10 \mathrm{mM}) \mathrm{dNTP}$, and $4 \mu \mathrm{l}$ diethylpyrocarbonate. The RNA was denatured at $65^{\circ} \mathrm{C}$ for 5 min and then cooled on ice. Master mix consisting of $10 \mu \mathrm{l}$ cDNA synthesis mix was added at $10 \mu \mathrm{l} \mathrm{sam-}$ ple and then incubated in a thermal cycler at $50^{\circ} \mathrm{C}$ for $50 \mathrm{~min}, 85^{\circ} \mathrm{C}$ for $5 \mathrm{~min}$, and then stored at $-20^{\circ} \mathrm{C}$.

The PCRs contained the following ingredients, $2 \mu \mathrm{l}$ sample, $2 \mu \mathrm{l}(20 \mu \mathrm{M})$ of forward primer, $2 \mu \mathrm{l}$
$(20 \mu \mathrm{M})$ of the reverse primer, and $45 \mu$ Platinum $^{\circledR}$ PCR SuperMix. The PCRs were run as follows, pre-denaturation at $95^{\circ} \mathrm{C}$ for $2 \mathrm{~min}$, and 40 cycles of denaturation at $95^{\circ} \mathrm{C}$ for $45 \mathrm{~s}$, annealing at $50^{\circ} \mathrm{C}$ for 1-min, extension at $72^{\circ} \mathrm{C}$ for $45 \mathrm{~s}$, and final extension at $72^{\circ} \mathrm{C}$ for $5 \mathrm{~min}$.

\section{Nested PCR}

For nested PCR, we used KAPA2G ${ }^{\mathrm{TM}}$ Fast Ready Mix 2X (KapaBiosystems). The PCRs contained the following ingredients, $12.5 \mu \mathrm{l}$ of 2x KAPA2G Fast Ready Mix, $1.25 \mu 1(10 \mu \mathrm{M})$ of forward primer, $1.25 \mu \mathrm{l}(10 \mu \mathrm{M})$ of reverse primer, $5 \mu \mathrm{l}$ of PCR product, and the addition of RNA-se free water until $25 \mu 1$. The PCRs were run as follows, pre-denaturation at $95^{\circ} \mathrm{C}$ for $2 \mathrm{~min}$, and 40 cycles of denaturation at $95^{\circ} \mathrm{C}$ for $20 \mathrm{~s}$, annealing at $49^{\circ} \mathrm{C}$ for $20 \mathrm{~s}$, extension at $72^{\circ} \mathrm{C}$ for $30 \mathrm{~s}$, and final extension at $72^{\circ} \mathrm{C}$ for $3 \mathrm{~min}$.

\section{Sequencing of nucleotide}

PCR products were sequenced using the Big Dyes TN kit (Applied Biosystems, USA) following the manufactories instructions, run, and analyses on an ABI PRISM ${ }^{\circledR} 3700$ DNA Analyzer. All products were sequenced in both directions. Identification of the resulting nucleotide sequence of ORF7 in local viruses was tested with BLAST in order to assure the specificity of the PCR. Multiple nucleotide ORF7 virus sequence was aligned by using Clustal $\mathrm{W}$ and compared with some isolate references (V2332, Lelystad, Ch-Ia, MLV, and JXA1).

\section{Phylogenetic analysis}

To analyze the ORF7 genes of isolates from North Sumatera, Indonesia, Phylogenetic reconstructions were generated using the neighbor-joining method by the computer program Molecular Evolutionary Genetics Analysis Version 6 based on the formulas of Kimura 2-parameter. The robustness of the phylogenetic analysis was determined by bootstrap analysis with 1000 replications.

\section{Results and Discussion \\ PCR}

About 10 of 47 samples were detected PRRSVpositive using external primers with the amplicon size of $703 \mathrm{bp}$. Of the 37 samples, which found negative by the external primer, 8 were PRRSV-positive by nested PCR using P71F and P71R primers with the amplicon size of 508bp. The result of amplicons ORF7 from Two-Step PCR and nested PCR through gel electrophoresis could be seen in Figure-1.

\section{Sequence analysis}

In this study, there were 18 complete sequences of ORF7, which came from 9 districts in North Sumatera. The specific primers ORFF and ORFR were designed to amplify gene target, which flanks from the partial of ORF6 to 3'UTR as long as $703 \mathrm{bp}$ of DNA fragment, this flanking region including the whole of ORF7 sequence. The whole ORF7 of the 


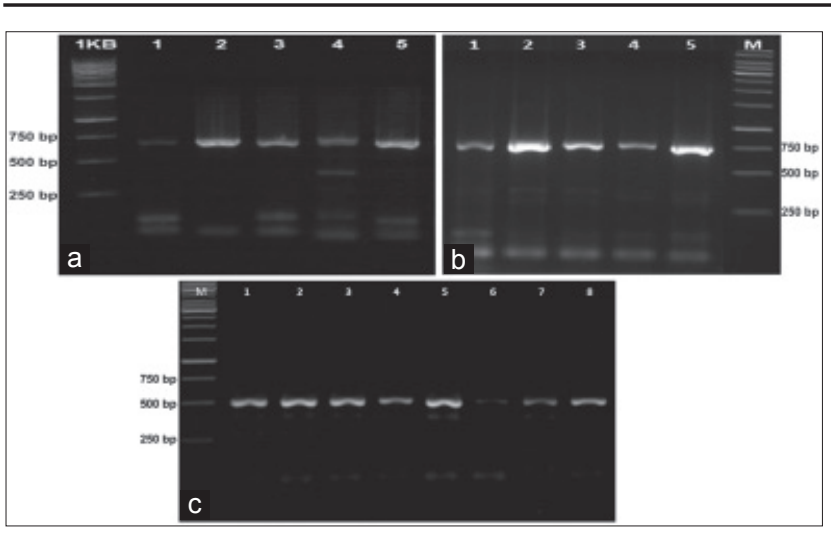

Figure-1: The result of amplification of two-step polymerase chain reaction (PCR) and nested PCR open reading frame 7 (ORF7) in agarose. (a) and (b), ORF7 was amplified in band 703bp, using ORFF and ORFR primers, (c) ORF7 was amplified with nested PCR in amplicons 508bp, using P71F and P7IR primers.

North Sumatera PRRSV sequences have the same nucleotides length in size of 369nt, which encoded 123 amino acids. There was no deletion and insertion in all local virus sequences. The nucleotide analysis indicated several points of silent mutations or missense mutations, compared with classic PRRS viruses (VR2332, MLV, and CH-1a) and HP-PRRS virus (JXA1).

$\mathrm{N}$ protein of PRRS virus has been recognized to have some areas [17]. The areas of nuclear localization signal 1 (NLS1) and NLS2 were the areas where amino acid mutations frequently occurred [17]. In North Sumatera PRRS viruses, amino acid mutations found in position 7 (K7R), 11 (R11K or R11I), 12 $(\mathrm{K} 12 \mathrm{~N})$, and 15 (D15N or D15Y) areas by which these positions have been previously reported as high variable region [17]. NLS2 area also underwent mutation points; the mutation point occurred in the position of 43 (K43R or K43N), 46 (K46R). The domain area IV, which was formed by amino acids 69-112, was one of the important antigenic domain areas in ORF7 [17], the mutation point occurred in the position of 91 (T91A) and 109 (H109Q). In the domain area V, in the position of amino acid 117, 11 local viruses were placed by Alanine, and 7 local viruses were placed by Valine. This area included the high variable area of $\mathrm{N}$ protein. Some mutation found in several North Sumatera viruses that indicate close related with JXA1 (K46R, T91A, H109Q, and V117A) but in the North Sumatera viruses, which were related closed to JXA1 virus, there are two differences amino acids in position 12 and 43 . The two amino acids were placed by aspartic acid and arginine (Figure-2).

NproteininPRRSvirushadmultifunction[18]; one of them was functioned as phosphoprotein Serine [19]. Phosphorylation in N protein occurred in the amino acid position 120 which was by Serine and all local viruses were placed by serine in this position (Table-1). Type 2 virus had three Cysteine residues, which were conserved; the three residues were located in the position of C23, C75, and C90, respectively [20]. These three positions were very important for virus effectiveness, and all local viruses indicated cysteine in this position (Table-1).

$\mathrm{N}$ protein in Type 2 virus had amino acid as binding domain place with fibrillarin in the position of amino acid 30-37 (IAQQNQSR). The result of the sequence of all local viruses, which indicated domain binding position with fibrillarin had conserved site (Table-1). The interesting thing of local viruses, which had the closeness to JXA1 virus, was that local viruses had unique amino acid; namely, in the position amino acid 12 and 43, were placed by Asparagine and Arginine. The virus which came from China (JXA1 and Ch-1a) and classic virus (VR 2332 and MLV) both positions were filled by Lysine. These two amino acids could be used as the marker of HP-PRRS virus which came from North Sumatera. Local viruses, which had the closeness to the classic virus in this position, were filled by Lysine (12K) and Aspartic Acid (43N). Pathogenicity of PRRS virus which also had its own characteristics had been reported in several countries [21-24].

\section{Phylogenetic analysis}

Phylogenetic analysis demonstrated that the 18 North Sumatera PRRS viruses were divided into two groups (Figure-3). The first was the viruses that genetically close related to JXAI virus with the viruses shared $91.6-99.1 \%$ in the level of nucleotide and 93.4-98.3\% level amino acids. High phylogenetic relatedness was found amongst the viruses belonging to the first group in this study (11 viruses in 2008). Both nucleotide and amino acid sequence identities of these viruses were high (97.5-99.1\%), indicative of genetic homogeneity. The source of virus transmission most probably came from HP-PRRS China virus in 2006 which spread throughout Asia, including Southeast Asia, and one of them was Indonesia. This was supported by the close relatedness of North Sumatera PRRS viruses to HP-PRRS (JXA1) virus.

The second group was considered of viruses that clustered in the same lineage with the VR2332 virus. The virus shared $93.0-100 \%$ nucleotide similarities in the ORF7 and $93.4-100 \%$ in the deduced amino acid sequences compared with VR 2332 virus. This indicates that Type 2 PRRS virus had spread widely in North Sumatera Province. The sequences of ORF7 compared with modified live vaccine (MLV) virus, showed $93.0-100 \%$ similarity in both nucleotide and amino acid sequences. High phylogenetic relatedness was found among the one virus (11.363.3 Medan) belonging to the second group in this study. The similarity with comparison with MLV virus was about $100 \%$ in both nucleotide and amino acid. This virus was a possibility that the vaccine virus has been circulating in North Sumatera.

The existence of North Sumatera viruses was related close to classic virus VR2332 and MLV, which indicated that there was the possibility for the virus 


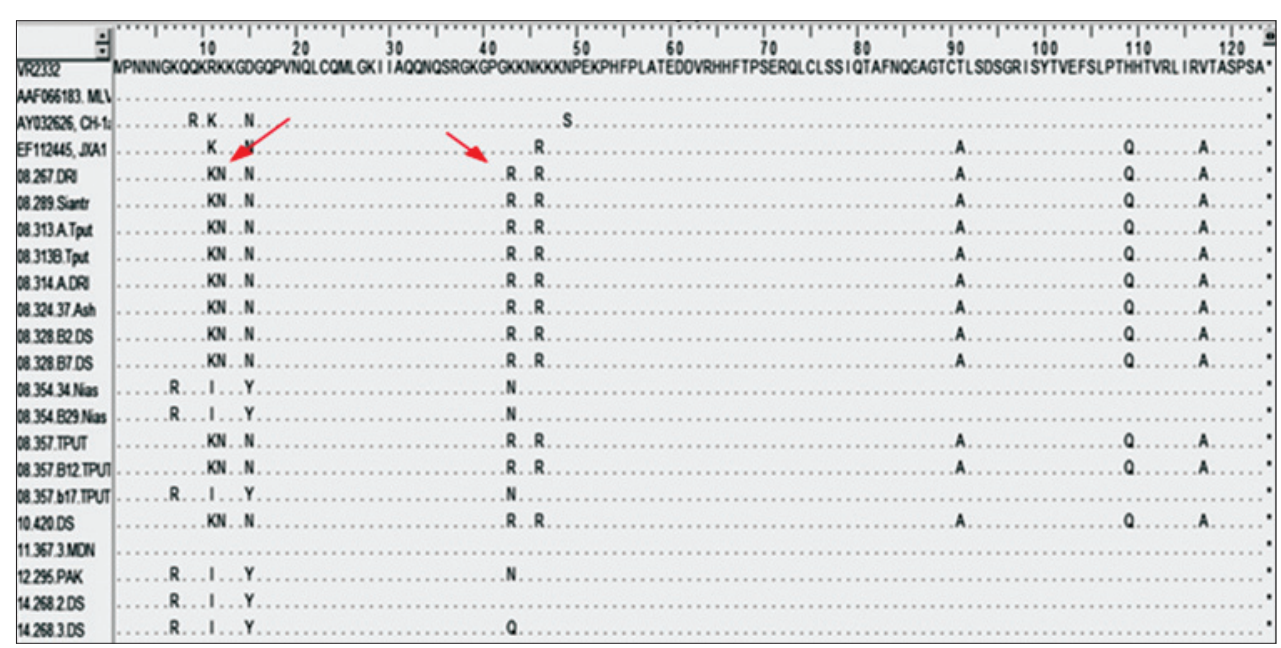

Figure-2: Multi alignment of 18 sequences of an amino acid of local viruses. Local viruses, which were related close to highly pathogenic porcine reproductive and respiratory syndrome (JXA1) reference virus, were found a unique amino acid. The two amino acids were placed by aspartic acid (12N) and arginine (43R) (red arrow).

Tabel-1: Amino acid variation in the important sites of ORF7.

\begin{tabular}{|c|c|c|c|c|c|c|c|c|c|c|c|c|}
\hline \multirow[t]{3}{*}{ Virus name } & \multicolumn{12}{|c|}{ Amino acid variation of ORF7 } \\
\hline & \multicolumn{3}{|c|}{$\mathbf{A}$} & \multirow{2}{*}{$\frac{\text { B }}{30-37}$} & \multicolumn{3}{|c|}{$\mathbf{C}$} & \multicolumn{4}{|c|}{ D } & \multirow{2}{*}{$\frac{E}{12 C}$} \\
\hline & 7 & 12 & 43 & & 23 & 75 & 90 & 46 & 91 & 109 & 117 & \\
\hline VR2332 & $\mathrm{K}$ & $\mathrm{K}$ & $\mathrm{K}$ & IAQNQSR & C & C & C & $\mathrm{K}$ & $\mathrm{T}$ & $\mathrm{H}$ & V & $\mathrm{S}$ \\
\hline MLV & - & - & - & - & - & - & - & - & - & - & - & - \\
\hline Ch-1a & - & - & - & - & - & - & - & - & - & - & - & - \\
\hline JXA1 & - & - & - & - & - & - & - & $\mathrm{R}$ & A & $\mathrm{Q}$ & A & - \\
\hline 08.267 Dairi & - & $\mathrm{N}$ & $\mathrm{R}$ & - & - & - & - & $\mathrm{R}$ & $A$ & $\mathrm{Q}$ & $A$ & - \\
\hline 08.289 Siantar & - & $\mathrm{N}$ & $\mathrm{R}$ & - & - & - & - & $\mathrm{R}$ & A & $\mathrm{Q}$ & A & - \\
\hline 08.313A Taput & - & $\mathrm{N}$ & $\mathrm{R}$ & - & - & - & - & $\mathrm{R}$ & A & $\mathrm{Q}$ & A & - \\
\hline 08.313B Taput & - & $\mathrm{N}$ & $\mathrm{R}$ & - & - & - & - & $\mathrm{R}$ & A & Q & A & - \\
\hline 08.314A Dairi & - & $\mathrm{N}$ & $\mathrm{R}$ & - & - & - & - & $\mathrm{R}$ & A & $\mathrm{Q}$ & A & - \\
\hline 08.324.37 Ash & - & $\mathrm{N}$ & $\mathrm{R}$ & - & - & - & - & $\mathrm{R}$ & A & $\mathrm{Q}$ & A & - \\
\hline 08.328.B2 DS & - & $\mathrm{N}$ & $\mathrm{R}$ & - & - & - & - & $\mathrm{R}$ & A & Q & A & - \\
\hline 08.328.B7 DS & - & $\mathrm{N}$ & $\mathrm{R}$ & - & - & - & - & $\mathrm{R}$ & A & $\mathrm{Q}$ & A & - \\
\hline 08.354.34 Nias & $\mathrm{R}$ & - & $\mathrm{N}$ & - & - & - & - & - & - & - & - & - \\
\hline 08.354.B29 Nias & $\mathrm{R}$ & - & $\mathrm{N}$ & - & - & - & - & - & - & - & - & - \\
\hline 08.357 Taput & - & $\mathrm{N}$ & $\mathrm{R}$ & - & - & - & - & $\mathrm{R}$ & A & Q & A & - \\
\hline 08.357.B12 Taput & - & $\mathrm{N}$ & $\mathrm{R}$ & - & - & - & - & $\mathrm{R}$ & A & Q & A & - \\
\hline 08.357.B17 Taput & $\mathrm{R}$ & - & $\mathrm{N}$ & - & - & - & - & - & - & - & - & - \\
\hline 10.420 DS & - & $\mathrm{N}$ & $\mathrm{R}$ & - & - & - & - & $\mathrm{R}$ & A & Q & A & - \\
\hline 11.367.3 MDN & - & - & - & - & - & - & - & - & - & - & - & - \\
\hline 12.295 PAK & $\mathrm{R}$ & - & $\mathrm{N}$ & - & - & - & - & - & - & - & - & - \\
\hline 14.268.2 DS & $\mathrm{R}$ & - & - & - & - & - & - & - & - & - & - & - \\
\hline 14.268.3 DS & $\mathrm{R}$ & - & $\mathrm{Q}$ & - & - & - & - & - & - & - & - & - \\
\hline
\end{tabular}

Abbreviation amino acids base on one letter symbols, $A=$ Unique Asam Amino (HP-PRRS like), $B=$ Binding domain with fibrillarin, $C=$ Cysteine conserved, $D=$ Amino acids similar to JXA1, E=Phosphorylation site, ORF7=Open reading frame 7, HP-PRRS=Highly pathogenic porcine reproductive and respiratory syndrome

which came from vaccine had caused infection in breeding pigs in North Sumatera. The implementation of vaccination, which was not in line with the rule or vaccinating sick animals, would bring about sickness in breeding pigs, which would eventually the incidence of PRRS case occurrence in pigpens and spread to other pigpens. Geographically, Nias District was bordered with the Indian Ocean and the mainland of Sumatera, but virus, which came from Nias and several other local viruses were close to the vaccine virus. Another assumption about the existence of the classic virus was that PRRS virus had long settled in North
Sumatera, along with the case of HP-PRRS China virus which spread to Southeast Asia, including North Sumatera. At the same time, the classic virus was also able to infect pigs, which brought about sickness. In order to know more about this case, it was necessary to study epidemiology deeply so that this case could be solved properly.

\section{Conclusion}

After analyzing local viruses which were found in North Sumatera, there were some important things, which could be concluded. First, PRRS virus, which 


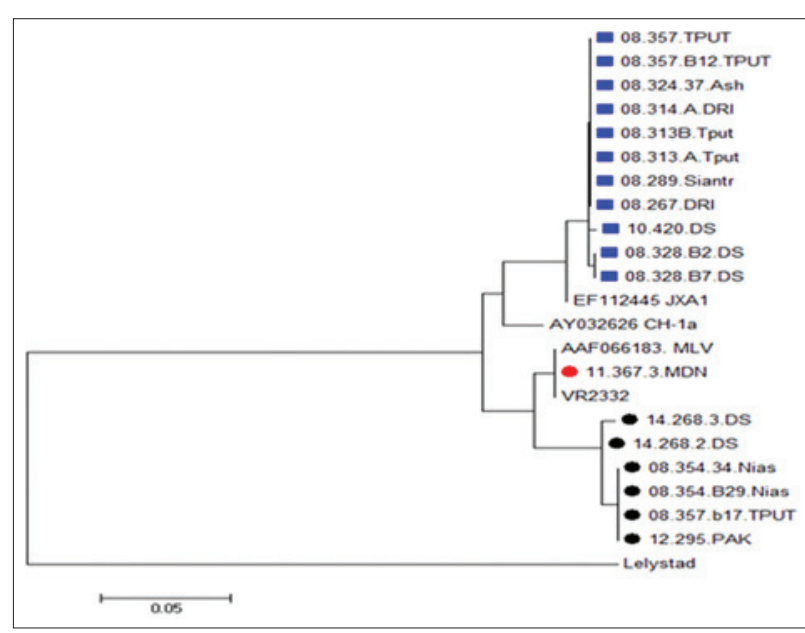

Figure-3: Phylogenetic tree, based on nucleotide sequences of open reading frame 7 local virus and some isolate references. Local viruses were distributed to 2 groups. Blue: Highly pathogenic porcine reproductive and respiratory syndrome cluster, black and red: classic virus cluster. Bootstrap values were calculated using 1000 replicates of the alignment.

spread in North Sumatera was included in Type 2 PRRS virus (NA); second, in its development, this virus was divided into two groups: Virus group which was close to HP-PRRS virus and virus group which was close to PRRS classic virus; and third, in the HP-PRRS virus group there were amino acids $12 \mathrm{~N}$ and $43 \mathrm{R}$ which could be used as the marker of PRRS virus which came from North Sumatera. The two amino acids were not found in other virus references and HP-PRRS China viruses. Further profound studies in various aspects could be conducted on these local viruses, particularly the function of amino acids $12 \mathrm{~N}$ and $43 \mathrm{R}$ as one of virus virulence factors.

\section{Author's Contributions}

FF was responsible for the collection of samples ADIC Medan at 2008-2014. AH did the PCR identification and RW phylogenic analysis. CRT drafted and revised the manuscript. All authors read and approved the final manuscript.

\section{Acknowledgments}

The authors are thankful to the Indonesian Agency for Agricultural Research and Development (IAARD), Indonesia, for funding this work.

\section{Competing Interests} interests.

The authors declare that they have no competing

\section{References}

1. Neumann, E.J., Kliebenstein, J.B., Johnson, C.D., Mabry, J.W., Bush, E.J., Seitzinger, A.H., Gree, A.L. and Zimmerman, J.J. (2005) Assessment of the economic impact of porcine reproductive and respiratory syndrome on swine production in the United States. J. Am. Vet. Med. Assoc., 227: 385-392.

2. Benfield, D.A., Nelson, E., Collins, J.E., Harris, L., Goyal, S.M., Robison, D., Christianson, W.T., Morrison, R.B.,
Gorcyca, D. and Chladek, D. (1992) Characterization of swine infertility and respiratory syndrome (SIRS) virus (isolate ATCC VR-2332). J. Vet. Diagn. Invest., 4: 127-133.

3. Wensvoort, G., Terpstra, C., Pol, J.M., Ter Laak, E.A., Bloemraad, M., de Kluyver, E.P., Kragten, C., van Buiten, L., den Besten, A. and Wagenaar, F. (1991) Mystery swine disease in the Netherlands: The isolation of Lelystad virus. Vet. Q., 13(3): 121-30.

4. Tian, K., Yu, X., Zhao, T., Feng, Y., Cao, Z., Wang, C., Hu, Y., Chen, X., Hu, D., Tian, X., Liu, D., Zhang, S., Deng, X., Ding, Y., Yang, L., Zhang, Y., Xiao, H., Qiao, M., Wang, B., Hou, L., Wang, X., Yang, X., Kang, L., Sun, M., Jin, P., Wang, S., Kitamura, Y., Yan, J. and Gao, G.F. (2007) Emergence of fatal PRRSV variants: Unparalleled outbreaks of atypical PRRS in Cina and molecular dissection of the unique hallmark. PLoS One, 2: 526. Available from: http://www.plosone.org.

5. Zhou, L. and Yang, H. (2010), Porcine reproductive and respiratory syndrome in China. Virus Res., 154: 31-37.

6. FAO. (2011) Focus on: Porcine reproductive and respiratory syndrome (PRRS) virulence jumps and persistent circulation in Southeast Asia. EMPRES, 5: 1-8.

7. Helen, R., Papadopoulou, C., Drew, T., Gresham, A. and Sabirovic, M. (2009) Highly pathogenic porcine reproductive and respiratory syndrome. Int Dis Monit Situat Assess, 23: 10 .

8. Nilubol, D., Tripipat, T., Hoonsuwan, T. and Kortheerakul, K. (2012) Porcine reproductive and respiratory syndrome virus, Thailand, 2010-2011. Emerg. Infect. Dis., 18(12): 2039-2043.

9. Dokland, T. (2010) The structural biology of PRRSV. Virus Res., 154: 86-97.

10. Meulenberg, J.J., Petersen-den Besten, A., De Kluyver, E.P., Moormann, R.J., Schaaper, W.M. and Wensvoort, G. (1995) Characterization of proteins encoded by ORFs 2 to 7 of Lelystad virus. Virology, 206: 155-163.

11. Yoo, D., Wootton, S.K., Li, G., Song, C. and Rowland, R.R. (2003) Colocalization and interaction of the porcine arterivirus nucleocapsid protein with the small nucleolar RNA associated protein fibrillarin. J. Virol., 77: 12173-12183.

12. Lin, C.N., Lin, W.H., Hung, L.N., Wang, S.Y. and Chiou, M.T. (2013) Comparison of viremia of Type 2 porcine reproductive and respiratory syndrome virus in naturally infected pigs by zip nucleic acid probe-based real-time PCR. BMC Vet. Res., 9: 181.

13. Wernike, K., Hoffmann, B., Dauber, M., Lange, E., Schirrmeier, H. and Beer, M. (2012) Detection and typing of highly pathogenic porcine reproductive and respiratory syndrome virus by multiplex real-time RT-PCR. PLoS One, 7(6): Available from: http://www.plosone.org. Last accessed on 25-01-2015.

14. Hao, X., Lu, Z., Kuang, W., Sun, P., Fu, Y., Wu, L., Zhao, Q., Bao, H., Fu, Y., Cao, Y., Li, P., Bai, X., Li, D. and Liu, Z. (2011) Polymorphic genetic characterization of the ORF7 gene of porcine reproductive and respiratory syndrome virus (PRRSV) in China. J. Virol., 8: 73.

15. Shi, Y., Hu, Z., Xiong, Z., Zhou, Y., Jin, X., Gu, C., Hu, X., Cheng, G., Song, N. and Zhang, W. (2013) Analysis of molecular variation of porcine reproductive and respiratory syndrome virus in Central China from 2006 to 2012. Arch. Virol., 158: 717-721.

16. Guarino, H., Goyal, S.M., Murtaugh, M.P., Morrison, R.B., Kapur, V. (1999) Detection of porcine reproductive and respiratory syndrome virus by reverse transcription-polymerase chain reaction using different regions of the viral genome. J. Vet. Diagn. Invest., 11: 27-33.

17. Rowland, R.R. and Yoo, D. (2003) Nucleolar-cytoplasmic shuttling of PRRSV nucleocapsid protein: A simple case of molecular mimicry or the complex regulation by nuclear import, nucleolar localization and nuclear export signal sequences. Virus Res, 95: 23-33.

18. Music, N. and Gagnon, C.A. (2010) The role of porcine 
reproductive and respiratory syndrome (PRRS) virus structural and non-structural proteins in pathogenesis. Anim. Health Res. Rev., 11(2): 135-163.

19. Wootton, S.K., Rowland, R.R. and Yoo, D. (2002) Phosphorylation of the porcine reproductive and respiratory syndrome virus nucleocapsid protein. J. Virol., 76: 10569-10576.

20. Wootton, S.K. and Yoo, D. (2003) Homo-oligomerization of the porcine reproductive and respiratory syndrome virus nucleocapsid protein and the role of disulfide linkages. $J$. Virol., 77: 4546-4557.

21. Hu, S.P., Zhang, Z., Liu, Y.G., Tian, Z.J., Wu, D.L., Cai, X.H. and He, X.J. (2012) Pathogenicity and distribution of highly pathogenic porcine reproductive and respiratory syndrome virus in pigs. Transbound Emerg. Dis., 60: 351-359.

22. Metwallly, S., Mohamed, F., Faaberg, K., Burrage, T., Prarat, M., Moran, K., Bracht, A., Mayr, G., Berninger, M.,
Koster, L., To, T.L., Nguyen, V.L., Reising, M., Landgraf, J., Cox, L., Lubroth, J. and Carrillo, C. (2010) Pathogenicity and molecular characterization of emerging porcine reproductive and respiratory syndrome virus in vietnam in 2007. Transbound Emerg. Dis., 57: 315-329.

23. Rossow, K.D., Collins, J.E., Goyal, S.M., Nelson, E.A., Christopher-Hennings, J. and Benfield, D.A. (1995) Pathogenesis of porcine reproductive and respiratory syndrome virus infection in gnotobiotic pigs. Vet. Pathol., 32: 361-373.

24. Zhou, Z., Ni, J., Cao, Z., Han, X., Xia, Y., Zi, Z., Ning, K., Liu, Q., Cai, L., Qiu, P., Deng, X., Hu, D., Zhang, Q., Fan, Y., Wu, J., Wang, L., Zhang, M., Yu, X., Zhai, X. and Tian, K. (2011) The epidemic status and genetic diversity of 14 highly pathogenic porcine reproductive and respiratory syndrome virus (HP-PRRSV) isolates from China in 2009. Vet. Microbiol., 150(3-4): 257-269.

$* * * * * * * *$ 